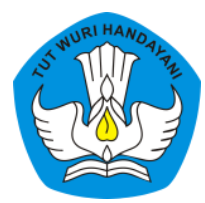

Page: 655-676

\title{
Peningkatan Hasil Belajar Peserta Didik Konsep Pra Aksara Melalui Strategi Digital Pre-Historic Assesment
}

\author{
Endang Winih Prasetyaningrum \\ Sekolah Menengah Pertama IT Ummu'l Quro Depok \\ Contributor Email: setya_endang@yahoo.com
}

Article Url: http://ojsdikdas.kemdikbud.go.id/index.php/didaktika/article/view/128

\begin{abstract}
The study entitled "Improving Student Learning Outcomes Class VII.B Pre-Literacy Concepts Through Digital Pre-Historic Assessment (DIPHA) Strategy" aims to find out Dipha's strategy can improve pre-literacy concept learning outcomes as well as to find out how much the achievement of learning material increases pre-literacy in grade VII students. B Ummu'l Quro Middle School Depok. This research is a classroom action research in class VII.B as many as 23 students for two cycles. Each cycle consists of two meetings. Based on the data obtained, learning using the Dipha strategy can improve learning outcomes. This success was marked by an increase in student learning outcomes including increasing mastery learning in attitude assessment by $33 \%$, knowledge assessment by $91 \%$, and skills by $74 \%$, the average test increased from $69 \%$ to $91 \%$. From the data acquisition and discussion it can be concluded that Dipha's strategy can improve the learning outcomes of grade VII.B students of SMP IT Ummu'l Quro Depok on the pre-script concept.
\end{abstract}

Keywords: Learning Outcomes; Strategies; Digital Pre-Historic Assesment 


\begin{abstract}
Abstrak
Penelitian yang berjudul "Peningkatan Hasil Belajar Peserta Didik Kelas VII.B Konsep Pra Aksara Melalui Strategi Digital Pre-Historic Assesment (Dipha)" ini bertujuan untuk mengetahui strategi Dipha dapat meningkatkan hasil belajar konsep pra aksara serta untuk mengetahui seberapa besar ketercapaian peningkatan hasil belajar materi pra aksara pada peserta didik kelas VII. B SMP IT Ummu'l Quro Depok. Penelitian ini merupakan penelitian tindakan kelas di kelas VII.B sebanyak 23 peserta didik selama dua siklus. Masingmasing siklus terdiri dari dua pertemuan. Berdasarkan data yang diperoleh, pembelajaran menggunakan strategi Dipha dapat meningkatkan hasil pembelajaran. Keberhasilan tersebut ditandai dengan adanya peningkatan ketercapaian hasil belajar peserta didik meliputi meningkatkan ketuntasan belajar pada penilaian sikap sebesar 33\%, penilaian pengetahuan sebesar sebesar $91 \%$, dan keterampilan sebesar 74\%, rata-rata tes meningkat dari $69 \%$ menjadi 91\%. Dari perolehan data dan pembahasan dapat disimpulkan bahwa strategi Dipha dapat meningkatkan hasil belajar peserta didik kelas VII.B SMP IT Ummu'l Quro Depok pada konsep pra aksara.
\end{abstract}

Keywords: Hasil Belajar; Strategi Pembelajaran; Digital Pre-Historic Assesment

\title{
A. Pendahuluan
}

Pemanfaatan teknologi bertujuan untuk mempermudah pekerjaan manusia dalam kehidupan sehari-hari. Perkembangan digital dalam dunia pendidikan juga memiliki pengaruh yang signifikan pada pola interaksi pendidik dan peserta didik. Pada masa generasi $\mathrm{Z}$ ini, pembelajaran perlu menyesuaikan dengan perkembangan teknologi yang pesat. Pembelajaran untuk generasi $Z$ saat ini akan menumbuhkan pengalaman-pengalaman baru (melihat, menyentuh, merasakan dan mengalami).

Pada kenyataan di serbagai daerah, pembelajaran sekarang ini masih banyak yang terpusat pada pendidik sehingga cenderung monoton. Kemampuan peserta didik dalam belajar belum terasah secara optimal. Situasi ini makin dikuatkan dengan hasil survey Programme for International Student Assesment (PISA) dan Trends In Internasional Math and Science Survey (TIMSS). Sejak keikutsertaannya dari tahun 1999, Indonesia belum mampu menempati peringkat atas. Pada tahun 2015 peringkat Indonesia pada PISA yaitu ada di angka 64 dari 72 negara sedangkan pada TIMSS Indonesia ada di 45 dari 48 negara. 
Kemajuan teknologi yang pesat belum diimbangi dengan kemampuan literasi peserta didik. Berdasarkan data survei dari Asesmen Kompetensi Peserta didik Indonesia (AKSI)/Indonesia National Assesment Program (INAP) dalam Buku Gerakan Literasi Sekolah, tahun 2016 skor literasi matematika peserta didik sebesar 77,13 (kurang), literasi membaca 46,83 (kurang), dan literasi sains 73,61 (kurang). Rendahnya tingkat literasi pada ketiga mata pelajaran ini sebagai akibat minat baca peserta didik masih cukup rendah.

Pendidik memiliki tantangan untuk memfasilitasi peserta didik belajar, sesuai kemampuan peserta didik dan perkembangan teknologi. Pendidik dapat menggunakan variasi strategi pembelajaran yang bersifat student center. Pendidik diharapkan mampu mendesain pembelajaran (by design) dan bukan muncul secara tiba-tiba (by chance). Dengan demikian pembelajaran lebih kontekstual.

Dalam pembelajaran yang kontekstual, diperlukan media pembelajaran yang sesuai. Media pembelajaran disesuai dengan kebutuhan akan menciptakan suatu kegiatan belajar yang menyenangkan. Di sini peran penting pendidik untuk mampu membuat sebuah revolusi dan inovasi pembelajaran. Revolusi dan inovasi pembelajaran diperlukan karena adanya berbagai tantangan zaman yang dihadapi, baik dari dalam maupun luar.

Perubahan dalam sistem pendidikan (proses belajar mengajar) di sekolah yaitu pada saat pembelajaran akan difasilitasi pula untuk penumbuhan perilaku unggul sehingga selalu dalam keseimbangan rasio dan akal budi. Peserta didik akan terbuka terhadap berbagai keterampilan untuk hidup di masa depan.

Pemilihan strategi pembelajaran yang tepat sangatlah perlu dilakukan. Pada mata pelajaran IPS kelas VII tentang pembabakan masa, juga membutuhkan strategi yang memberikan gambaran bagi peserta didik. Pada konsep tersebut masih dianggap sebagai konsep ilmu yang sulit dipahami. Hal tersebut dapat dilihat. Hal tersebut dapat dilihat dari hasil belajar peserta didik pada tema 3 yang abstrak hanya mencapai ketuntasan $22 \%$. Pembelajaran tema 4 tentang masa pra aksara pada tahun-tahun sebelumnya selalu memeroleh ketuntasan yang lebih rendah dari tema 3 . 
Untuk itu, perbaikan dalam strategi pembelajaran harus dilakukan. Pada penelitian ini, digunakan strategi peningkatan hasil belajar melalui Dipha. Pemilihan strategi Dipha ini sesuai dengan karakteristik peserta didik yang menyukai perangkat digital, dan dalam mengembangkan pengalaman yang menantang yang melibatkan aktivitas menyenangkan. Peserta didik merasakan langsung pembelajaran menggunakan indera sehingga pembelajaran di kelas menjadi lebih bermakna.

Penelitian yang relevan dengan strategi digital adalah penelitian yang dilakukan oleh Nurhalimah (2011) dalam skripsinya yang berjudul "Peningkatan hasil belajar Matematika dengan menggunakan Interactive Teaching and Learning Strategies pada peserta didik kelas VIII MTs Syekh Yusuf Sungguminasa Gowa". Strategi digital yang digunakan adalah memanfaatkan media komputer sebagai alat komunikasi jarak jauh.

Penggunaan strategi pembelajaran menggunakan digital melibatkan peserta didik secara aktif. Peserta didik dilibatkan dalam semua kegiatan belajar baik itu membaca, menulis, mendengar dan berbicara. Pada akhirnya peserta didik akan merasa nyaman belajar dan senang belajar. Selain itu juga dapat menghilangkan rasa jenuh dan bosan pada diri peserta didik. Oleh karenanya, diciptakan strategi pembelajaran Dipha ( Digital Pre Historic Assesment).

Peserta didik kelas VII.B SMP IT Ummu'l Quro Depok memiliki karakteristik yang cenderung sama dengan kelas VII lainnya. Oleh karenanya penelitian tindakan kelas dengan judul "Peningkatan Hasil Belajar Peserta Didik Kelas VII..B Konsep Pra Aksara Melalui Strategi Digital Pre-Historic Assesment (Dipha)" ini dilakukan sebagai upaya untuk mengetahui adanya perubahan peningkatan hasil belajar dengan melakukan uji tindakan pada peserta didik di sekolah ini.

Rumusan masalah pada penelitian ini adalah apakah strategi Dipha dapat meningkatkan hasil belajar konsep pra aksara peserta didik kelas VII.B SMP IT Ummu'l Quro Depok, serta bagaimana ketercapaian peningkatan hasil belajar konsep pra aksara pada peserta didik kelas VII.B SMP IT Ummu'l Quro Depok dengan menggunakan strategi Dipha. 
Sejalan dengan itu maka tujuan dalam penelitian ini adalah untuk mengetahui strategi Dipha pada pembelajaran di kelas VII B SMP IT Ummu'l Quro Depok sehingga dapat meningkatkan hasil belajar konsep pra aksara, serta untuk mengetahui seberapa besar ketercapaian peningkatan hasil belajar materi pra aksara pada peserta didik kelas VII B SMP IT Ummu'l Quro Depok.

Melalui inovasi dalam penelitian ini, manfaat yang dapat diperoleh bagi peserta didik yakni agar mendapatkan pengalaman belajar yang menyenangkan karena menggunakan strategi digital terutama pada pembelajaran IPS, agar terjadi pengembangan karakter peserta didik seperti tanggung jawab, disiplin, semangat belajar. Bagi pendidik, penelitian ini diharapkan membuat pendidik menjadi lebih kreatif, menjadikan pendidik lebih berinovasi dalam pembelajaran, serta Meningkatkan profesionalisme pendidik. Bagi pihak sekolah, hasil penelitian ini kiranya dapat digunakan sebagai referensi pembelajaran untuk mewujudkan tercapainya visi dan misi sekolah yaitu melalui teknologi sebagai media dalam pembelajarannya. Hasil penerapan strategi “Digital Pre-Historic Assesment (Dipha)" dapat digunakan oleh pendidik lain di lingkungan SMP IT Ummu'l Quro Depok dalam memberikan pelayanan terhadap peserta didik untuk peningkatan kualitas pembelajaran di sekolah.

Karya inovasi pembelajaran ini diharapkan dapat memberi dampak yang positif terutama bagi dinas pendidikan, sekolah, pendidik dan peserta didik. Dengan meningkatnya profesionalisme, kreativitas dan wawasan pendidik berdampak terhadap kemampuan pendidik dalam mengajar. Dengan semakin baiknya kemampuan pendidik dalam mengajar maka akan meningkatkan prestasi peserta didik.

\section{B. Metode}

Peserta didik SMP terutama kelas VII banyak yang menganggap mata pelajaran IPS adalah ilmu pengetahuan yang bersifat hafalan dan merasa kebosanan saat bertemu dengan mata pelajaran tersebut pada tahun-tahun sebelumnya. Hal serupa juga dialami oleh peserta didik kelas 
VII.B SMP IT Ummu'1 Quro Depok. Peserta didik kesulitan untuk menghafal pada pembelajaran pra aksara yang bersifat teori karena pembelajaran masih terfokus pada pendidik. Untuk itu, dikembangkan satu inovasi pembelajaran yang mengajak bermain yang sedang belajar, karena cara belajar yang benar adalah ketika anak berada pada zona nyaman.

Pembelajaran konsep pra aksara sebelumnya sangat menjenuhkan karena masih berfokus pada pendidik. Keterlibatan peserta didik dalam proses pembelajaran sangat sedikit sehingga didesain untuk mencapai tujuan pembelajaran. Kegiatan ini melibatkan aktivitas membahagiakan bagi peserta didik. Peserta didik merasakan langsung dengan segenap pancaindranya di dalam situasi nyata atau kontekstual.

Tantangan terbesar bagi pendidik yang mengajar generasi zaman sekarang adalah generasi yang melek internet, mereka juga lebih mudah menerima dan belajar hal-hal baru. Mereka akan menjadi generasi yang lebih mandiri, melek bahasa inggris serta lebih cendrung pendiam. Oleh karena itu pendidik harus mampu berinovasi dalam meramu pembelajaran di kelas.

Keinginan dan kegelisahan untuk melakukan pembaharuan kualitas pembelajaran di kelas inilah yang mendorong peneliti untuk membuat strategi pembelajaran yang lebih baik lagi dengan bantuan peran media pembelajaran yang menunjang kelancaran penyampaian konsep materi. Sehingga diharapkan dengan penggunakan strategi dan media yang tepat dapat membuat peserta didik lebih memahami konsep materi dan pada akhirnya adanya peningkatan hasil belajar peserta didik.

Bentuk usaha yang dilakukan yaitu dengan mengembangkan sendiri strategi Dipha sebuah strategi pembelajaran yang memanfaatkan ketersediaan sarana prasarana di sekolah. Strategi ini diperuntukkan untuk membantu peserta didik dan pendidik pada pembelajaran konsep pra aksara, mata pelajaran IPS kelas VII.B sekolah menengah pertama.

Materi pembelajaran pra aksara memiliki karakteristik tersendiri dibandingkan materi pembelajaran lainnya. Pra aksara merupakan keadaan dimana belum munculnya mahluk hidup, kejadian ini berlangsung selama jutaan tahun berlalu. Kondisi ini sulit divisualkan secara nyata, apalagi 
sudah berlangsung dalam kurun waktu yang lampau. Strategi Dipha yang digunakan merupakan suatu terobosan baru dalam memudahkan peserta didik memahami materi pra aksara.

Strategi Dipha berangkat dari ide peneliti sebagai pengembangan penggunaan media Microsoft Power Point dalam pembelajaran sebelumnya. Hasil penilaian pembelajaran ini yang menggunakan kertas, diperoleh hasil banyak peserta didik yang belum tuntas.

Pengembangan strategi digital dengan Dipha memiliki kelebihan sebagai solusi dari permasalahan semangat belajar dan hasil belajar peserta didik yang rendah. Kelebihan ini menjadikan strategi digital sebagai solusi peningkatan hasil belajar. SMP IT Ummu'l Quro Depok memiliki keunggulan satu peserta didik difasilitasi dengan satu laptop untuk kegiatan pembelajaran.

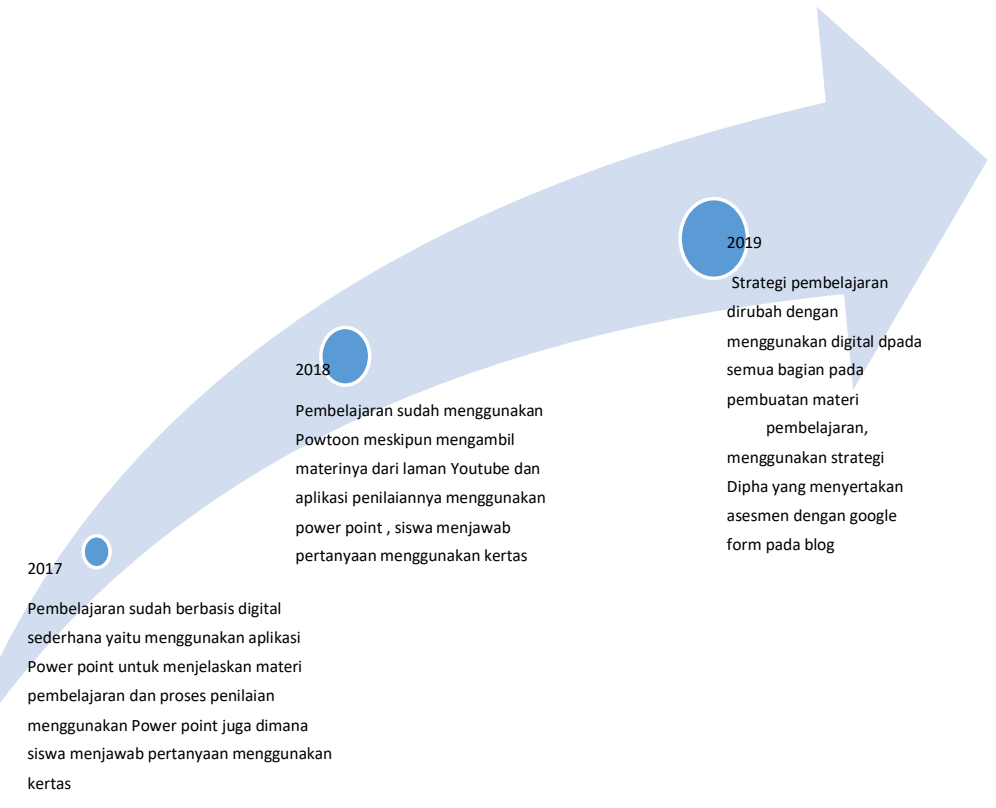

Gambar 1 Pembelajaran materi pra aksara 3 tahun terakhir

Berangkat dari sejumlah teori yang telah diuraikan sebelumnya dan ide penelitian, bahwa pembelajaran konsep pra aksara akan semakin bermakna bila menggunakan strategi digital dengan perincian konsep 
yang ringkas dan jelas serta menggunakan bahasa yang ringan, interaktif dan menarik sesuai dengan PUEBI (Pedoman Umum Ejaan Bahasa Indonesia).

Strategi pembelajaran ini yang kemudian diberi nama Dipha, diyakini lebih baik dan lebih efektif untuk digunakan di sekolah manapun. Keyakinan peneliti didasari pada beberapa hasil inovasi pembelajaran lain yang dikembangkan sebelumnya yang telah membawa dampak positif pada peningkatan hasil belajar peserta didik. Pada beberapa inovasi sebelumnya lebih sederhana dan belum mampu menjelaskan secara lebih jelas dan terperinci mengenai tahapan periodesasi masa pra aksara.

Dalam pengembangannya strategi digital pada materi pra aksara telah direvisi beberapa kali sesuai gambar 8, berdasarkan masukan dari beberapa pendidik dan pengawas pendidikan. Beberapa tahapan revisi yang telah dilakukan bertujuan untuk meningkatkan strategi pembelajaran yang menarik, bermanfaat dan mudah difahami oleh peserta didik.

Beberapa perbedaan yang mendasari pada strategi pembelajaran digital bila dibandingkan dengan strategi pembelajaran sebelumnya. Pada strategi sebelumnya menggunakan perangkat komputer dan teknik penilaian semi digital, dan proses pembelajaran pun semi digital. Pada strategi digital kali ini semua proses pembelajaran dilakukan dengan menggunakan aplikasi digital. Strategi pembelajaran digital juga merupakan jawaban atas proses pembelajaran pada era 4.0 yang kegiatannya banyak sekali melibatkan beberapa kemampuan peserta didik seperti kolaborasi dan komunikasi.

Selain menggunakan strategi digital dan membangun pembelajaran 4.0, media simulasi Dipha menggunakan script yang ditulis oleh peserta didik. Peserta didik secara berkelompok memikirkan ide dan membaca referensi pendukung pembuatan script. Selanjutnya peserta didik juga membuat koding dan di aplikasi ini. Kelebihan strategi ini adalah peserta didik dapat mengembangkan animasi pendukung agar lebih menarik dan mudah dipahami. 


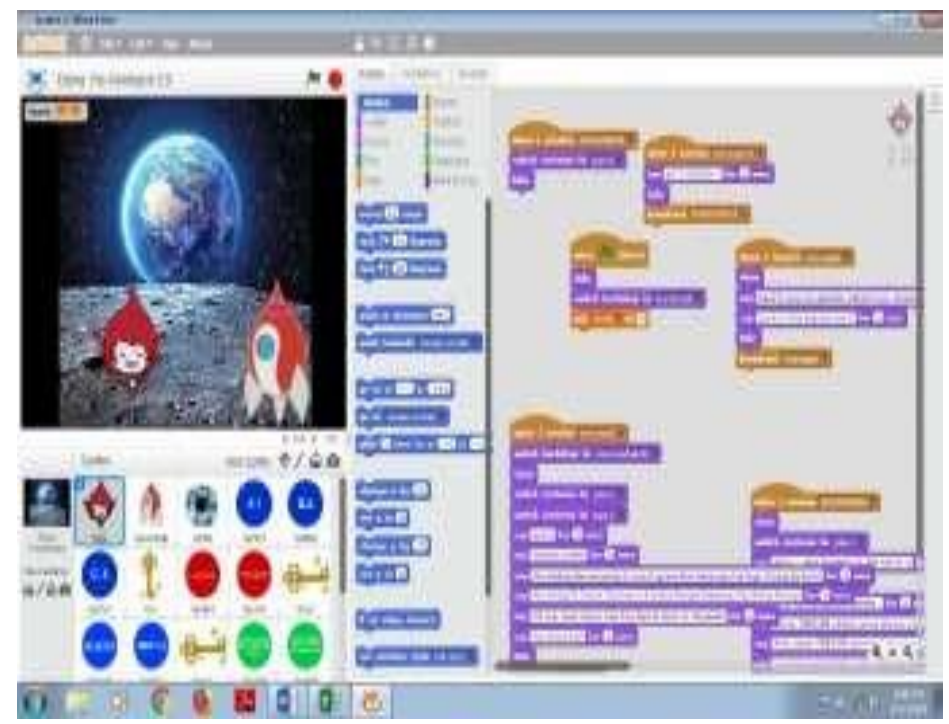

Gambar 2 Tampilan Digital Pre-Historic

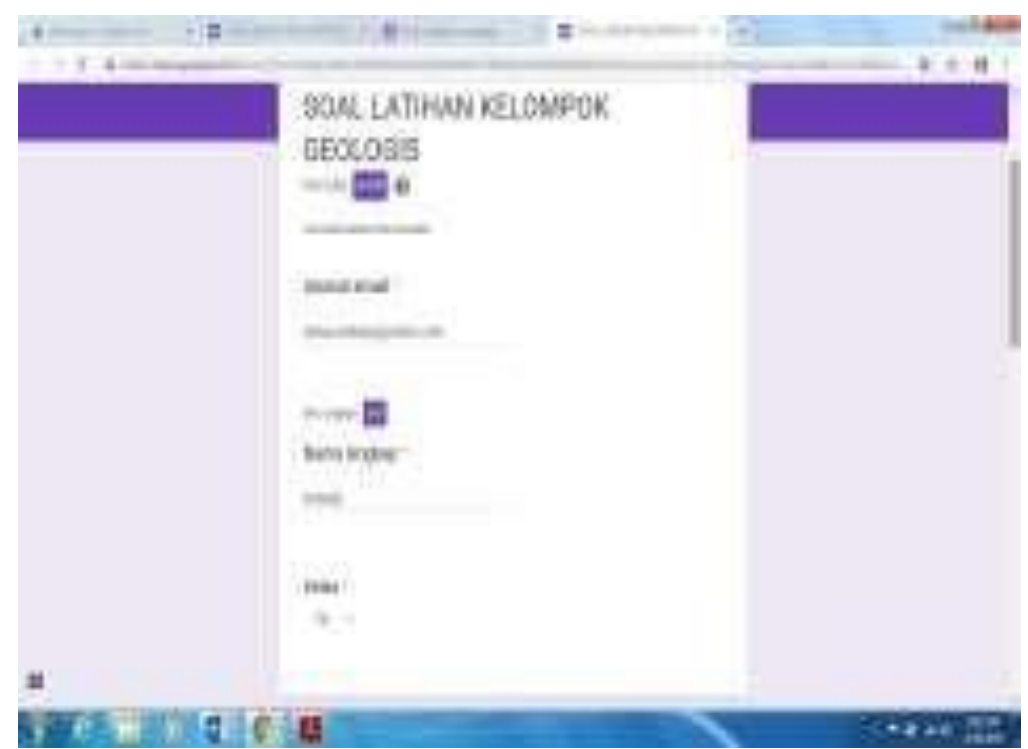

Gambar 3 Tampilan Digital Assesment

Metode yang digunakan peneliti dalam penelitian ini adalah Penelitian Tindakan Kelas (PTK). Model PTK yang peneliti gunakan adalah model Kemmis and Taggart dalam Taniredja (2010) digambarkan sebagai berikut. 


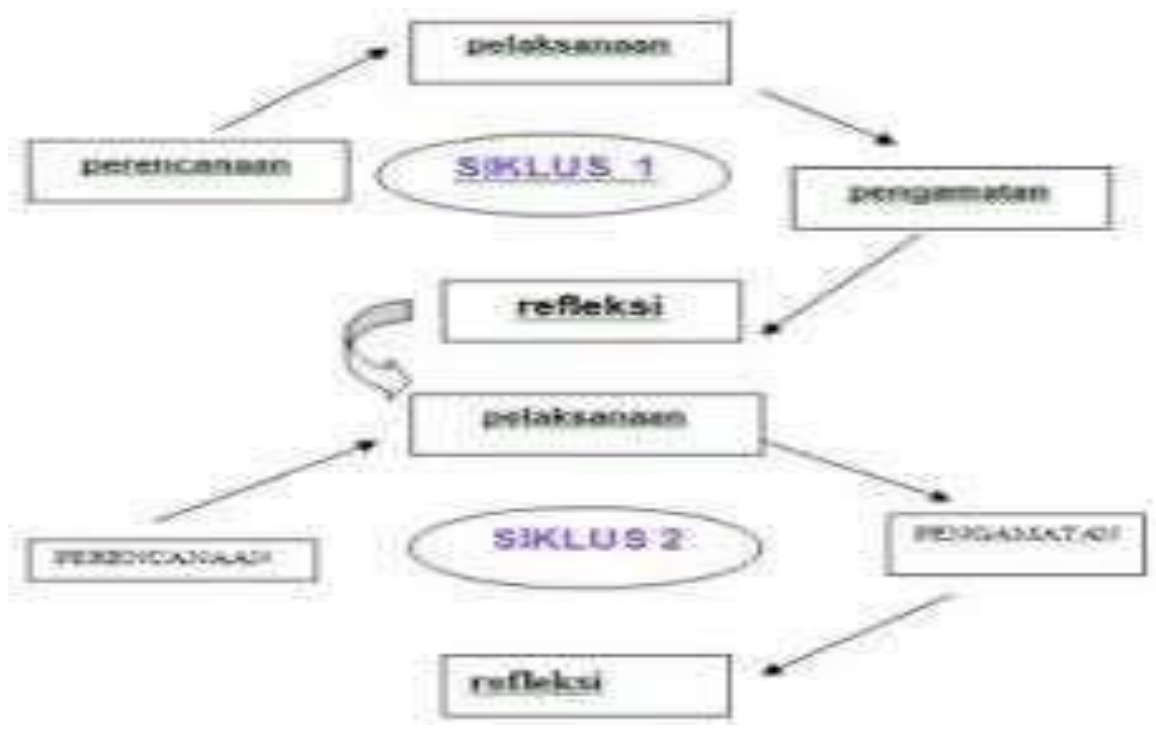

Gambar 4 Model Kemmis dan Taggart

\section{Perencanaan Siklus I}

\section{Pertemuan I}

Aplikasi praktis diawali dengan perencanaan yaitu penyiapan keperluan bagi pembelajaran. Pendidik membuka RPP. Pendidik selanjutnya menyiapkan media Dipha The Geologist dalam kelas untuk pelaksanaan pembelajarannya serta menyiapkan instrumen penilaiannya.

\section{Pertemuan II}

Pada pertemuan kedua pendidik berencana mengembangkan karya Dipha The History of Geologist dengan penilaian digital perorangan. Pendidik juga menyiapkan RPP, menyiapkan media Dipha The Geologist dalam kelas untuk pelaksanaan pembelajarannya serta menyiapkan instrumen penilaiannya.

\section{Pelaksanaan Siklus I}

\section{Pertemuan I}

Pelaksanaan pembalajaran pertemuan pertama dilaksanakan pada tanggal 19 Februari 2019. Di kelas VII B SMP IT Ummu'l Quro Depok 
sebanyak 23 peserta didik. Pembelajaran dilaksanakan pada jam ketiga dan keempat. Pembelajaran dilaksanakan sesuai dengan langkah-langkah pembelajaran dalam RPP yaitu:

Pendidik membuka pembelajaran dengan kegiatan berdoa, memberikan salam, absen kehadiran peserta didik dan pengkondisian kelas. Setelah itu, memberikan apresepsi dengan meminta peserta didik menulis sebuah kata dan meminta 2 orang untuk memaju, lalu peserta didik yang pertama menunjukkan tulisannya dan peserta didik kedua membaca isi tulisannya. Setelah peserta didik membacakan isi tulisan di depan kelas, dilanjutkan pendidik menyampaikan judul materi yang akan diajarkan serta menyampaikan tujuan pembelajaran.

Pada tahap kegiatan inti, pendidik membagi kelompok kedalam 6 kelompok kecil dengan anggota 3-4 orang, setelah membagi kelompok pendidik menjelaskan cara kerja Dipha yang akan digunakan.

Apabila peserta didik sudah siap melakukan kegiatan pembelajaran maka peserta didik diminta membuka Dipha yang sudah ada di laptop peserta didik. Saat peserta didik mengaktifkan Dipha, pendidik memberitahukan mengenai kegiatan apa saja yang akan dilakukan peserta didik.

Pendidik menginfokan tentang penilaian sikap berikut indikator yang akan dinilai pada saat proses diskusi kelompok. Pendidik meminta peserta didik membuat catatan ringkasan atas materi yang ada dalam game, dan memberitahukan tujuan pembuatan catatan ini adalah untuk menjawab penilaian digital yang akan diberikan oleh pendidik. Selanjutnya peserta didik membuat 5 pertanyaan dari apa yang mereka baca.

Setelah selesai membuat pertanyaan. Perwakilan peserta diminta untuk memberikan pertanyaan tersebut kepada kelompok lain, dan begitu seterusnya. Setelah selesai semua,peserta didik diminta membuat catatan kecil yang isinya kesimpulan yang didapatkan dari proses pembelajaran. Perwakilan dari kelompok diminta membacakan kesimpulan dari kelompok di depan kelompok lain. Setelah seluruh kelompok menyampaikan kesimpilannya, pendidik kembali menyampaikan kesimpulan sebagai bentuk konfirmasi atas 
hasil pembelajaran. Sebagai bagian akhir pembelajaran pendidik meminta peserta didik mengisi kuisioner yang telah disiapkan oleh pendidik.

\section{Pertemuan II}

Pelaksanaan pembelajaran pertemuan kedua dilaksanakan pada hari rabu tanggal 20 Februari 2019. Pembelajaran dilaksanakan pada jam kelima dan keenam. Pembelajaran dilaksanakan sesuai dengan langkahlangkah pembelajaran dalam RPP yaitu pendidik membuka pembelajaran dengan kegiatan berdoa, memberikan salam, absen kehadiran peserta didik dan pengkondisian kelas. Setelah itu, memberikan apresepsi dengan pendidik menjelaskan bahwa kita akan bermain tebak gambar sebagai bentuk penguatan atas informasi yang didapat oleh peserta didik sebelumnya. Pendidik menyiapkan sebuah benda terkait materi sebelumnya. Peserta didik diminta untuk membuat 1 pertanyaan, karena di kelas ada 23 maka setiap peserta didik mendapatkan 2 kali kesempatan.

Pada tahap kegiatan inti, pendidik meminta peserta didik duduk sesuai dengan kelompoknya. Apabila peserta didik sudah siap melakukan kegiatan pembelajaran maka peserta didik diminta membuka Dipha yang sudah ada di laptop peserta didik. Saat peserta didik mengaktifkan Dipha, pendidik memberitahukan mengenai kegiatan apa saja yang akan dilakukan peserta didik.

Pendidik menginfokan tentang kegiatan yang akan dilakukan yaitu rangkaian kegiatan seperti pada pertemuan I yang ditambahkan dengan penilaian. Diakhir pembelajaran, peserta didik membuka blog yang pendidik tuliskan di laptop pendidik dan mulai mengerjakan tugas mandiri dalam durasi waktu 1 menit. Peserta didik yang berhasil menyelesaikan menjawab semua soal dengan benar dan tepat waktu akan menjadi pemenang.

\section{Hasil Observasi Aktivitas Peserta Didik Pertemuan I Siklus I}

Pengamatan aktivitas peserta didik menggunakan lembar observasi peserta didik. Dalam lembar tersebut terdapat 4 aspek pengamatan keterampilan 
dan 3 aspek pengamatan sikap. Aspek pengamatan keterampilan terdiri atas keterampilan menggoprasikan Dipha, keterampilan menuliskan ide serta keterampilan mengomunikasikan informasi. Dari hasil pengamatan, atas keterampilan mengoperasikan Dipha: 12 siswa sudah dapat mengoprasikan Dipha tanpa bantuan dari rekan sejawat, sedangkan 5 siswa yang mengoprasikan Dipha dengan bantuan teman, 3 siswa mampu mengoprasikan Dipha namun secara berkelompok, 2 siswa mengalami kesulitan mengoprasikan Dipha, 1 siswa tidak bisa menggunakan Dipha.

Untuk keterampilan menuliskan ide: 8 peserta didik yang dapat menuliskan ide dengan bahasa yang baik dan benar, 8 peserta didik dalam menuliskan ide harus dibimbing dalam pemilihan bahasa, 3 peserta didik dalam menuliskan ide harus berkelompok, 2 peserta didik kesulitan menuliskan ide, 2 peserta didik tidak bisa menuliskan ide.

Keterampilan mengomunikasikan pemikiran: 6 peserta didik yang dapat mengomunikasikan pemikiran dengan Bahasa yang baik dan benar, 5 peserta didik dalam mengomunikasikan pemikiran harus dibimbing tata caranya, 5 peserta didik dalam mengomunikasikan hanya bisa di depan kelompoknya, 4 peserta didik kesulitan mengomunikasikan pemikiran, 3 peserta didik tidak bisa mengomunikasikan pemikiran.

\section{Pertemuan II Siklus I}

Pengamatan aktivitas peserta didik menggunakan lembar observasi peserta didik. Dalam pengamanat yang dilakukan oleh guru dibantu rekan sejawat ditemukan beberapa peningkatan hasil belajar siswa yaitu terdapat $22 \%$ peserta didik yang mendapatkan nilai diatas 82 . Hal ini disimpulkan oleh peneliti bahwa $70 \%$ peserta didik sudah mencapai ketuntasan diatas $85 \%$, sehingga PTK ini akan dilanjutkan pada Siklus II.

Pada observasi kali ini terdapat 4 aspek yang diamati oleh rekan sejawat, pada saat pendidik melakukan pembelajaran yakni, kemampuan membuka pembelajaran, kemampuan mengelola kelas, kemampuan menilai, kemampuan menutup pembelajaran. Dalam hal ini, pendidik dilihat oleh rekan sejawat hanya mampu membuka pembelajaran hal ini terlihat dari 
adanya penjelasan tentang tujuan pembelajaran dan penilaian sedangkan kemampuan mengelola dan menutup pembelajaran belum terlihat.

Pelaksanaan pembelajaran dengan menggunakan strategi Dipha berjalan dengan tertib. Peserta didik termotivasi untuk berperan aktif dalam pembelajaran. Tampak peserta didik aktif dalam mengerjakan soal individu.

Selama proses pembelajaran dilaksanakan, satu observer melakukan penilaian terhadap proses pembelajaran. Hasil pengamatan akan disampaikan pada bagian berikutnya. Hasil pengamatan peneliti menunjukkan bahwa strategi Dipha sangat menarik perhatian peserta didik, sehingga seluruh peserta didik fokus mengikuti pembelajaran.

Pelaksanaan pembelajaran dengan menerapkan strategi Dipha berjalan dengan tertib. Semua peserta didik tampak mengikuti pembelajaran dengan senang. Seluruh peserta didik menjawab pertanyaan dan mengerjakan tugas pada penilaian digital secara individu dan kelompok dengan tanggung jawab.

\section{Perencanaan Siklus II}

\section{Pertemuan I}

Aplikasi praktis diawali dengan perencanaan yaitu penyiapan keperluan bagi pembelajaran berupa rpp, laptop, instrumen penilaian, media Dipha. Pendidik menyiapkan media Dipha The Arceologist and Culture dalam kelas.

\section{Pertemuan II}

Pada pertemuan kedua pendidik berencana mengembangkan karya Dipha The History of Archeology dengan penilaian digital perorangan dan kelompok. Pendidik juga menyiapkan RPP.

\section{Pelaksanaan Siklus II}

\section{Pertemuan I}

Pelaksanaan pembalajaran pertemuan pertama dilaksanakan pada tanggal 26 Februari 2019 di kelas VII B. Pembelajaran dilaksanakan pada 
jam ketiga dan keempat. Pembelajaran dilaksanakan sesuai dengan langkah-langkah pembelajaran dalam RPP yaitu Pendidik membuka pembelajaran dengan kegiatan berdoa, memberikan salam, absen kehadiran peserta didik dan pengkondisian kelas. Setelah itu, memberikan apresepsi dengan meminta peserta didik menulis 5 pertanyaan yang ingin diketahui dari materi yang akan diajarkan.

Pada tahap kegiatan inti, pendidik meminta peserta didik duduk pada kelompoknya, selanjutnya pendidik menjelaskan mengenai penugasan apa saja yang akan diberikan berikut penilaiannya. Apabila peserta didik sudah siap melakukan kegiatan pembelajaran maka peserta didik diminta membuka buku pelajaran.

Pendidik menyampaikan teknis kegiatan pada siklus II yaitu: (1). Peserta didik diminta untuk duduk sesuai kelompoknya, (2). Peserta didik membuka bab periodesasi masa arkeologi dan corak kebudayaan, (3). Peserta didik menyimak informasi yang diberikan oleh buku tersebut, dan menuangkan ke dalam tulisan yang berupa kata kunci, (4). Kelompok yang selesai menyimak informasi lalu menuliskan kata kunci kedalam stick note yang sudah disiapkan oleh pendidik di meja per kelompok, tujuan dari kata kunci tersebut adalah untuk membantu peserta didik saat menjawab pertanyaan yang akan diberikan per kelompok. (5). Setelah menyelesaikan membuat kata kunci, peserta didik diminta menerangkan pada kelompok lain.

\section{Pertemuan II}

Pelaksanaan pembelajaran pertemuan kedua dilaksanakan pada tanggal 27 Februari 2019. Pembelajaran dilaksanakan pada jam kelima dan keenam. Pembelajaran dilaksanakan sesuai dengan langkah-langkah pembelajaran dalam RPP yaitu:

Pendidik membuka pembelajaran dengan kegiatan berdoa, memberikan salam, absen kehadiran peserta didik dan pengkondisian kelas. Setelah itu, memberikan apresepsi dengan meminta peserta didik menulis sebuah kata dan meminta 2 orang untuk maju, lalu peserta didik yang pertama 
menunjukkan tulisannya dan peserta didik kedua membaca isi tulisannya. Setelah peserta didik membacakan isi tulisan di depan kelas, dilanjutkan pendidik menyampaikan judul materi yang akan diajarkan serta menyampaikan tujuan pembelajaran.

Pada tahap kegiatan inti, pendidik meminta peserta didik duduk di bangkunya, apabila peserta didik sudah siap melakukan kegiatan pembelajaran maka peserta didik diminta membuka DIPHA yang sudah ada di laptop peserta didik. Saat peserta didik mengaktifkan Dipha, pendidik memberitahukan mengenai kegiatan apa saja yang akan dilakukan peserta didik.

Sebelum peserta didik mengerjakan soal, semua kelompok akan bersaing dalam kuis yang dibuat oleh pendidik. Kuis tersebut menggunakan KAHOOT, teknis permainannya yaitu: (1). Setiap kelompok wajib masuk ke dalam laman kahoot, (2). Perwakilan kelompok memasukkan sandi yang sudah diberikan oleh pendidik, (3). Setiap kelompok wajib menjawab pertanyaan dengan cepat dan benar, tujuan permainan ini adalah untuk Ice Breaking sebelum peserta didik mengerjakan 10 soal pilihan ganda.

Pendidik menginfokan tentang penilaian digital yang akan diberikan. Selanjutnya peserta didik membuka blog yang pendidik tuliskan di papan tulis dan mulai mengerjakan tugas mandiri dalam durasi waktu 1 menit. Peserta didik yang berhasil menyelesaikan menjawab semua soal dengan benar dan tepat waktu akan menjadi pemenang.

\section{Hasil Observasi Aktivitas Peserta Didik Pertemuan I Siklus II}

Pengamatan aktivitas peserta didik menggunakan lembar observasi peserta didik. Dalam lembar tersebut terdapat 4 aspek pengamatan yaitu keterampilan menggunakan Dipha, menuliskan ide, mengomunikasikan. Pada aspek pertama, Dari hasil pengamatan, atas keterampilan mengoperasikan Dipha: 17 siswa sudah dapat mengoprasikan Dipha tanpa bantuan dari rekan sejawat, sedangkan 4 siswa yang mengoprasikan Dipha dengan bantuan teman, 1 siswa mampu mengoprasikan Dipha namun secara 
berkelompok, 1 siswa mengalami kesulitan mengoprasikan Dipha, 0 siswa tidak bisa menggunakan Dipha.

Untuk keterampilan menuliskan ide: 15 peserta didik yang dapat menuliskan ide dengan bahasa yang baik dan benar, 3 peserta didik dalam menuliskan ide harus dibimbing dalam pemilihan bahasa, 2 peserta didik dalam menuliskan ide harus berkelompok, 2 peserta didik kesulitan menuliskan ide, 1 peserta didik tidak bisa menuliskan ide.

Keterampilan mengomunikasikan pemikiran: 14 peserta didik yang dapat mengomunikasikan pemikiran dengan Bahasa yang baik dan benar, 6 peserta didik dalam mengomunikasikan pemikiran harus dibimbing tata caranya, 1 peserta didik dalam mengomunikasikan hanya bisa di depan kelompoknya, 1 peserta didik kesulitan mengomunikasikan pemikiran, 1 peserta didik tidak bisa mengomunikasikan pemikiran.

Selain pengamatan keterampilan, peneliti juga melakukan pengamatan atas sikap peserta didik. Sikap yang diamati peneliti dalam pembelajaran yakni berhubungan dengan tanggung jawab, disiplin dan semangat. Pada siklus I pertemuan I ditemukan oleh peneliti untuk tanggung jawab sebanyak 10 peserta didik sedangkan pada siklus II pertemuan I sebanyak 13, disiplin pada siklus I pertemuan I sebanyak 4 peserta didik sedangkan pada siklus II pertemuan I sebanyak 6, semangat dalam pembelajaran pada siklus I pertemuan I sebanyak 3 peserta didik sedangkan pada siklus II pertemuan I sebanyak 4. Peneliti menyimpulkan bahwa terdapat peningkatan sikap peserta didik dari siklus I pertemuan I ke siklus II pertemuan I, sehingga ketuntasan belajar peserta didik pada aspek sikap dinyatakan baik.

\section{Pertemuan II Siklus II}

Pengamatan aktivitas peserta didik menggunakan lembar observasi peserta didik. Dalam pengamanat yang dilakukan oleh guru dibantu rekan sejawat ditemukan beberapa peningkatan hasil belajar siswa yaitu terdapat $91 \%$ peserta didik yang mendapatkan nilai diatas 82 . Hal ini 
disimpulkan oleh peneliti bahwa $90 \%$ peserta didik sudah mencapai ketuntasan diatas $85 \%$, sehingga PTK ini berhasil.

Pada observasi kali ini terdapat 4 aspek yang diamati oleh rekan sejawat, pada saat pendidik melakukan pembelajaran yakni, kemampuan membuka pembelajaran, kemampuan mengelola kelas, kemampuan menilai, kemampuan menutup pembelajaran. Dalam hal ini, pendidik dilihat oleh rekan sejawat pada semua aspek.

Pelaksanaan pembelajaran dengan menerapkan strategi Dipha berjalan dengan tertib. Semua peserta didik tampak mengikuti pembelajaran dengan senang. Seluruh peserta didik menjawab pertanyaan dan mengerjakan tugas pada penilaian digital secara individu dan kelompok dengan tanggungjawab.

\section{Hasil dan Pembahasan}

Pembelajaran tema 4 Masyarakat Indonesia pada masa pra aksara dengan menggunakan strategi Dipha efektif meningkatkan hasil belajar peserta didik. Berdasarkan data yang diperoleh maka analisis data yang dapat diambil adalah sebagai berikut maka hasil observasi aktivitas pendidik selama proses pembelajaran pada siklus I yaitu pada aktivitas kemampuan membuka pembelajaran dan kemampuan mengelola kelas sudah terlihat hal ini ditunjukkan 50\% sementara aspek yang lain seperti kemampuan menilai dan menutup pembelajaran belum terlihat. Sedangkan pada siklus II aktivitas pendidik sudah terlihat semua sehingga mengalami peningkatan sebesar $100 \%$.

Aktivitas pendidik mengalami peningkatan sebesar 50\%. Pada pertemuan pertama masih ada 2 aspek yang belum muncul dan pada pertemuan kedua semua aspek telah muncul. Hal tersebut menunjukkan bahwa pendidik semakin lancar dalam mengelola kelas menjadi pembelajaran menarik dan menyenangkan. Hasil Observasi Peserta didik dapat dilihat dalam tabel berikut. 
Tabel 1 Hasil rekapitulasi observasi peserta didik

\begin{tabular}{|l|c|c|c|c|}
\hline & \multicolumn{2}{|c|}{ Siklus I } & \multicolumn{2}{c|}{ Siklus II } \\
\hline & $\begin{array}{c}\text { Jumlah } \\
\text { Peserta Didik }\end{array}$ & Prosentase & $\begin{array}{c}\text { Jumlah } \\
\text { Peserta Didik }\end{array}$ & Prosentase \\
\hline Dapat menggunakan strategi Dipha & 12 & $52 \%$ & 17 & $74 \%$ \\
\hline Dapat menuliskan ide & 8 & $35 \%$ & 15 & $65 \%$ \\
\hline Dapat mengomunikasikan ide & 6 & $26 \%$ & 14 & $61 \%$ \\
\hline
\end{tabular}

Dari tabel di atas dapat kita ketahui bahwa pada pertemuan pertama peserta didik yang dapat menggunakan strategi Dipha sebanyak $52 \%$ dan jumlah itu kemudian meningkat pada pertemuan kedua menjadi $74 \%$. Pada aspek kedua peserta didik yang dapat menuliskan ide juga mengalami peningkatan sebesar $30 \%$ dan dapat mengomunikasikan ide $35 \%$.

Tabel 2 Ketuntasan hasil belajar peserta didik

\begin{tabular}{|l|c|c|}
\hline \multicolumn{1}{|c|}{ Tuntas/Tidak Tuntas } & Siklus I & Siklus II \\
\hline Peserta didik Tuntas Pembelajaran & 5 & 21 \\
\hline Peserta didik tidak Tuntas Pembelajaran & 18 & 2 \\
\hline Prosentase Ketuntasan & $22 \%$ & $91 \%$ \\
\hline
\end{tabular}

Tabel tersebut menunjukkan adanya peningkatan ketuntasan belajar peserta didik dari pertemuan I sebesar 22\% menjadi 91\%. Peningkatan tersebut juga menunjukkan penelitian berhasil, dibuktikan dengan $90 \%$ peserta didik mengalami peningkatan ketuntasan pembelajaran.

Tahap ini membahas tentang (1). strategi Dipha dapat meningkatkan hasil belajar materi pra aksara pada peserta didik kelas VII B SMP IT Ummu'l Quro Depok (2). ketercapaian peningkatan hasil belajar materi pra aksara pada peserta didik kelas VII B SMP IT Ummu'l Quro Depok dengan menggunakan strategi DIPHA.

Strategi DIPHA dapat meningkatkan hasil belajar materi pra aksara pada peserta didik kelas VII B SMP IT ditunjukkan dengan hasil observasi aktivitas pendidik dalam melaksanakan pembelajaran serta hasil observasi aktivitas peserta didik dalam mengikuti pembelajaran. Hasil observasi aktivitas pendidik pada siklus I mendapatkan persentase $50 \%$ dalam kriteria baik, siklus II mendapat persentase $100 \%$ dalam kriteria sangat baik sehingga terjadi kenaikan 50\%. Sedangkan hasil observasi aktivitas peserta didik pada siklus I dalam mengerjakan 
penugasan individu mendapatkan presentase 22\% dalam kriteria baik, pada siklus II mendapatkan presentase 91\% dalam kriteria sangat baik, ada kenaikan $69 \%$. Sedangkan untuk aktivitas peserta didik pada keterampilan mengalami peningkatan dari siklus I mendapatkan presentase $52 \%$ menjadi $74 \%$ di siklus II.

Dengan demikian, maka dapat disimpulkan bahwa penggunaan strategi digital efektif untuk meningkatkan hasil belajar dalam mata pelajaran IPS materi Pra Aksara pada peserta didik kelas VII B SMP IT Ummu'1 Quro Depok Tahun Pelajaran 2018/2019.

\section{Penutup}

Dari data dan pembahasan yang telah dilakukan dapat disimpulkan bahwa strategi Dipha dapat meningkatkan hasil belajar peserta didik kelas VII.B SMP IT Ummu'l Quro Depok pada konsep pra aksara. Hal ini dibuktikan dengan adanya peningkatan ketuntasan belajar pada siklus I sebesar $22 \%$ menjadi $91 \%$ pada siklus II. Ketercapaian peningkatan hasil belajar peserta didik kelas VII.B SMP IT Ummu'l Quro Depok pada konsep pra aksara adalah adanya peningkatan rata-rata hasil tes pada siklus I sebesar 69\% menjadi 91\% pada siklus II. Pada penilaian keterampilan peningkatan pada siklus I 52\% menjadi $74 \%$ pada siklus II. Pada penilaian sikap peningkatan pada siklus I $25 \%$ menjadi $33 \%$ pada siklus II. Strategi belajar menggunakan Dipha ini dapat direkomendasikan bagi pendidik lainya sebagai cara untuk meningkatkan hasil belajar peserta didik di SMP.

\section{Ucapan Terimakasih}

Peneliti ucapkan terimakasih kepada Bapak H. Ali Fikri Piyar, Lc, MA. Dewan Pembina Yayasan Ummu'l Quro Depok. Ibu Hj. Siti Rukoyah, S.P. Kepala Bidang Penjamin Mutu Pendidikan Yayasan Ummu'l Quro Depok. Seluruh dewan pendidik SMP IT Ummu'l Quro Depok serta seluruh peserta didik Kelas VII. B tahun ajaran 2018/2019. Serta kepada Kepala SMP IT Ummu'l Quro Depok yang telah memberikan izin untuk melakukan penelitian. 
Semoga hasil karya inovasi ini akan berguna bagi pengembangan kreativitas serta inovasi dalam pembelajaran di kelas khususnya dalam pembelajaran Ilmu Pengetahuan Sosial. Sehingga diharapkan dapat turut serta dalam meningkatkan kualitas Pendidikan di Indonesia pada umumnya dan di Kota Depok.

\section{Daftar Referensi}

Arikunto, Suharsimi. 2009. Dasar-dasar Evaluasi Pendidikan. Jakarta: Bumi Aksara

Ahmad Susanto. 2013. Teori Belajar dan Pembelajaran di Sekolah Dasar. Jakarta : Kencana Prenadamedia Group

Dimyati., \& Mudjiono. 2013. Belajar Dan Pembelajar. Jakarta : Rineka Cipta

Irawan, Randy. 2018. Pengembangan E-Learning berbasis MOODLE Dalam Peningkatan Pemahaman Lagu pada Pembelajaran Bahasa Inggris. Jurnal Inovasi Teknologi Pendidikan,5 (1), 1-11

Munir. 2009. Pembelajaran Jarak Jauh Berbasis Teknologi Informasi dan Komunikasi. Bandung: Alfabeta

Nugroho, R. Arifin. 2018. Kemampuan Berpikir Tingkat Tinggi. Jakarta: PT. Gramedia Widiasarana Indonesia

Nurhalimah. 2011. Peningkatan Hasil Belajar Matematika dengan menggunakan Interactive Teaching and Learning Strategis Pada Peserta didik Kelas VIIIA MTs Syekh Yusuf Sungguminasa Gowa. Skripsi, UIN Alauddin Makasar. Diakses dari https://www.scribd.com/doc/288276856/Nurhalima-S-Pd-pdf

Sanjaya, Wina. 2010. Strategi Pembelajaran Berorientasi Standar Proses Pendidikan. Jakarta: Prenada Media Group

Suprijono, Agus. 2009. Cooperative Learning Teori dan Aplikasi PAIKEM. Yoyakarta: Pustaka Pelajar

Suryani, Nunuk, dkk, 2018. Media Pembelajaran Inovatif dan Pengembangannya. Bandung: PT. Remaja Rosdakarya

Taniredja, Tukiran, dkk. 2012. Model-Model Pembelajaran Inovatif. Bandung: Alfabeta. 
Vol. 4, No. 3, November 2020 